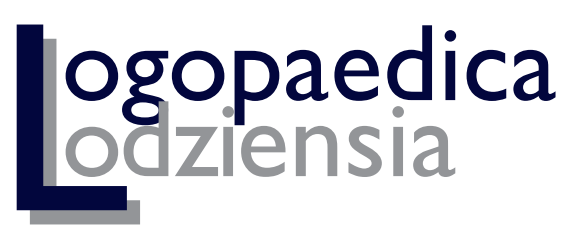

$\mathrm{Nr} 4(2020)$

D0l: http://dx.doi.org/10.18778/2544-7238.04.07

Marta Kosicka*, Ewa Gacka** iD

\title{
Knowledge of Teachers and Students of Early School Education and Pre-School Education on the Dysfunctions and Parafunctions of the Orofacial Complex
}

Wiedza nauczycieli oraz studentów edukacji wczesnoszkolnej i wychowania przedszkolnego na temat dysfunkcji oraz parafunkcji zespołu ustno-twarzowego

Keywords: speech therapy, orofacial complex, dysfunctions, parafunctions, knowledge, teachers, students, early school education, pre-school education

Słowa kluczowe: logopedia, zespół ustno-twarzowy, dysfunkcje, parafunkcje, wiedza, nauczyciele, studenci, edukacja wczesnoszkolna, wychowanie przedszkolne

\section{Introduction}

Among all specialists who cooperate with speech therapists it is educators that may perform a major role in activities aimed at preventing language communication disorders. To do this, they should have the basics of knowledge on speech therapy "[...] a teacher being aware of the issues in question may, first of all, prevent some speech disorders [...]" [Błachnio, 2012, p. 93]. An adequately prepared educator will not only notice the child's problems during educational activities, but will also give parents information on the necessity and possibility of consultation with, for instance, a speech therapist or psychologist. Good observers will also notice difficulties of a child in reading or tracing, they will pay attention to articulation difficulties

\footnotetext{
* Municipal Kindergarten no. 215, 11/13 Budowlana street, 93-356 Łódź, e-mail: mjk10@wp.pl.

** University of Lodz, Faculty of Philology, Institute of Polish Philology and Logopaedics, Department of Polish Dialectology and Logopaedics, 171/173 Pomorska street, 90-236 Łódź, e-mail: ewa .gacka@uni.lodz.eu, ORCID: https://orcid.org/0000-0002-1873-7487.
} 
as well as abnormalities which promote the development of speech impediments, such as nail biting, biting pencils, chewing on clothes, persistent breathing through the mouth. In this idealistic scenario, however, there is an array of questions: Is it so? Do teachers and students of pre-school and early school education have the basic knowledge on the conditions of normal speech development as well as its disorders? Do they know which factors may cause disorders in phoneme realization? Do they have the knowledge on the abnormalities in the orofacial area (dysfunctions and parafunctions) which may cause speech impediments? Do they consider this knowledge acquired first during their studies and then in their educational work to be sufficient? Are teachers and students capable of preventing unfavourable habits? Answers to these questions are essential as the educator will be "[...] a link in early identification of children requiring specialist speech therapy assistance" provided that they have adequate competences [Gacka, 2013b, p. 60].

\section{The orofacial complex: the meaning of the term}

Unambiguity and precision in defining the terms used by the researchers is of great importance for the clarity of considerations. In specialist literature the term the orofacial complex is used denoting such structures as: jaw bones, mandible, teeth, temporomandibular joints, neuromuscular system and coordination centres of the central nervous system [cf. Masztelarz, 1981, p. 18; Pluta-Wojciechowska, 2011, p. 128].

The man uses the skeletal and muscular structures connected with the orofacial complex, particularly muscles of the face, oral cavity, pharynx and esophagus, for different activities, such as [Pluta-Wojciechowska, 2011, p. 128]:

- instinctive oral reactions;

- breathing;

- taking food and drinking;

- orofacial sensorics allowing to feel sensations such as taste, temperature and touch;

- resting the head, e.g. during sleep;

- orofacial self-stimulation, self-examination, self-experimentation and self-play;

- physiological activities, such as yawning or coughing;

- harmful habits concerning the masticatory apparatus, i.e. parafunctions;

- expressing feelings through mimicry;

- articulation.

The abnormalities in the construction and functioning of the orofacial complex may, therefore, adversely affect the way of realizing phonemes, impair the development of primal activities of speech, leading to the occurrence and perpetuation of speech impediments [cf. Zadurska et al., 2007; Malicka, 2017; Pluta-Wojciechowska, 2017]. 


\section{Dysfunctions and parafunctions of the orofacial complex}

In orthodontic literature dysfunctions are referred to as "impaired mechanisms of activities which involve the masticatory apparatus" [Grosfeldowa, 1981, p. 72]. They include, for instance, incorrect positioning of the infant during sleep; faulty posture; abnormal breathing - through the mouth; abnormal swallowing, e.g. with the tongue between the teeth; abnormal chewing or biting (e.g. on one side); incorrect pronunciation [Łabiszewska-Jaruzelska, 1983, p. 157]. Such pathogenic activity patterns may be easily perpetuated, particularly during infancy and post-infancy, which is caused by the inertia of motor responses and insufficient maturity of inhibition processes [Grosfeldowa, 1981, p. 73]. Parafunctions, in turn, are referred to as "activities which have the nature of motor stereotypes unconnected with physiological processes or mechanisms" [Grosfeldowa, 1981, p. 73]. They include harmful habits which are often repeated and performed unconsciously or unintentionally [ŁabiszewskaJaruzelska, 1983, p. 163]. Parafunctional habits may be divided into two categories: occlusal parafunctions and non-occlusal parafunctions [Kleinrok, 1992, p. 20]. The first one, occlusal parafunctions, i.e. teeth clenching and chattering as well as teeth gnashing (bruxism), involve contact with opposing teeth [Kleinrok, 1992, p. 20]. In turn, non-occlusal parafunctions do not involve contact with opposing teeth, and they include: sucking or chewing e.g. a dummy, fingers, lips, bedsheets; biting nails or cuticles around them; chewing or forcing and putting different objects between the teeth, such as toys or pencils, which may cause opening of interdental spaces; hooking the finger over the lower teeth and pulling the mandible forward, keeping the tongue or moving the tongue in the oral cavity into the specific area, as well as habitual resting the chin or mandibular angle on hands [cf. Łabiszewska-Jaruzelska, 1983, p. 163; Kleinrok, 1992, p. 20; Rokitiańska, 2004, p. 55]. Parafunctions may appear in diversified forms throughout the whole life, yet it is in the period of infancy and childhood that they appear with the greatest frequency [Grosfeldowa, 1981, pp. 73, 78]. Both occlusal parafunctions and non-occlusal parafunctions are considered to be concurrently caused by the psychogenic factor [Kleinrok, 1992, p. 20].

\section{Methodology of own research}

The aim of the conducted research was to explore the knowledge of teachers and students of pre-school and early school education on dysfunctions and parafunctions of the orofacial complex and their impact on the development of articulation abnormalities. So far, there have been no studies to probe teachers' knowledge in this area. The presented research was aimed at answering the following questions:

- "What do the examined persons know about the harmfulness of particular dysfunctions and parafunctions of the oral-facial complex?"; 
- "What do the respondents know about the relationship between the dysfunctions and parafunctions of the oral-facial complex and articulatory disorders?";

- "Do the subjects know how to prevent parafunctions and dysfunctions of the oral-facial syndrome?";

- "Do the respondents consider this knowledge to be necessary for pre-school and early school education teachers?".

The analyzed group comprised 60 people, including 30 teachers working with preschool and early primary school children as well as 30 students of pedagogy with specialization of pre-school and early school education of the University of Lodz. The research was conducted among final-year BA students. Only women were among the respondents. The average age of teachers was 38.5 years, while students were 22.7 years old. Teachers participating in the research have worked in the teaching profession for 11 years on average. The work experience of teachers ranged from 1 year to 39 years.

The research uses the method of diagnostic survey which allows to analyze opinions and knowledge of the selected group on the given subject [cf. Pilch, Bauman 2001, p. 80; Łobocki, 2006, p. 244] and the survey technique adequate to it which was anonymous. The survey questionnaire consisted of closed questions (the respondents were to choose one answer from a number of answers) as well as open questions which provided the opportunity to give independent answers.

\section{Research results}

\section{Knowledge of the subjects about the harmfulness of particular dysfunctions and parafunctions of the oral-facial syndrome}

Teachers and students taking part in the research were asked to indicate the activities (belonging to dysfunctions of the orofacial complex ${ }^{1}$ ) which they consider to be harmful, undesirable or abnormal. They were supposed to make a selection from among the following answers listed in the survey questionnaire: breathing through the mouth, biting and chewing on one side, swallowing with the tongue between the teeth or near the lower teeth, swallowing with the tongue at the hard palate. It was also possible to mark the answer "I don't know". As many as $97 \%$ of students and $100 \%$ of teachers regarded permanent breathing through the mouth as abnormal. Only one student, which represents $3 \%$ of all the respondents, gave the incorrect explanation, saying that this method of breathing is normal.

1 The survey questionnaire intentionally does not use the term "dysfunctions" of the orofacial complex in the question so as not to prompt any answers (the prefix "dys" denotes an incorrect course of the given activity). 
In response to the question about biting and chewing food on one side, $93 \%$ of respondents in both groups decided that this activity is abnormal (correctly). Two persons from the group of students and two teachers considered this activity not to be a deviation from the norm.

In turn, $63 \%$ of students and $70 \%$ of teachers recognized the normal way of swallowing, namely with the tongue on the hard palate. Incorrect answers included: swallowing with the tongue at the lower teeth, which was marked by $17 \%$ of students and $17 \%$ of teachers as well as performing this activity with the tongue thrust between the teeth, which in the opinion of $13 \%$ students is not a deviation from the norm. $7 \%$ of students and $13 \%$ of teachers do not know how the activity of normal swallowing should be performed.

While completing the survey the respondents were asked to mark which of the presented activities are permissible and treated as normal in children. The activities to be assessed included:

a) sucking the dummy/teether;

b) drinking from a bottle (with a teat);

c) breathing through the mouth (during sleep);

d) breathing through the mouth while watching television or listening to a story;

e) nail biting;

f) biting pencils;

g) thumb sucking;

h) sucking/biting hair;

i) swallowing with the tongue between the teeth;

j) cheek/lip biting;

k) chewing on clothes or objects;

l) teeth gnashing;

m) resting chin on hands;

n) involuntary repetitive tongue movement in the oral cavity area;

o) and forcing objects between the teeth.

The respondents' answers are illustrated by Chart 1 .

As many as 19 students (63\%) and 7 teachers (23\%) considered thumb sucking to be within the norm. Activities which were considered permissible by the largest number of respondents included drinking from a bottle (with a teat) as indicated by 26 students and 28 teachers as well as sucking the dummy/teether as indicated by 23 students and 25 teachers. The following activities were regarded as harmless: thumb sucking chosen by 19 students and 7 teachers; involuntary repetitive tongue movement in the oral cavity area selected by 11 students and 7 teachers as well as forcing objects between the teeth marked by 8 students and 6 educators. Among the remaining dysfunctions and parafunctions of the orofacial complex which were deemed permissible by the respondents were: breathing through the mouth (during sleep) which received 7 votes from each group; breathing through the mouth while 
watching television or listening to a story as indicated by 5 students and 3 teachers; nail biting which was marked by 1 teacher, chewing on a pencil as selected by 1 student and 2 teachers; sucking/biting hair which was chosen by 2 teachers; swallowing with tongue between the teeth as chosen by 3 students and 7 teachers; cheek/lip biting selected by 1 student; chewing on clothes or objects which was marked by 6 students and 2 teachers; teeth gnashing as selected by 3 students and 1 teacher while resting chin on hands was indicated as correct activity by 4 students and 1 teacher.

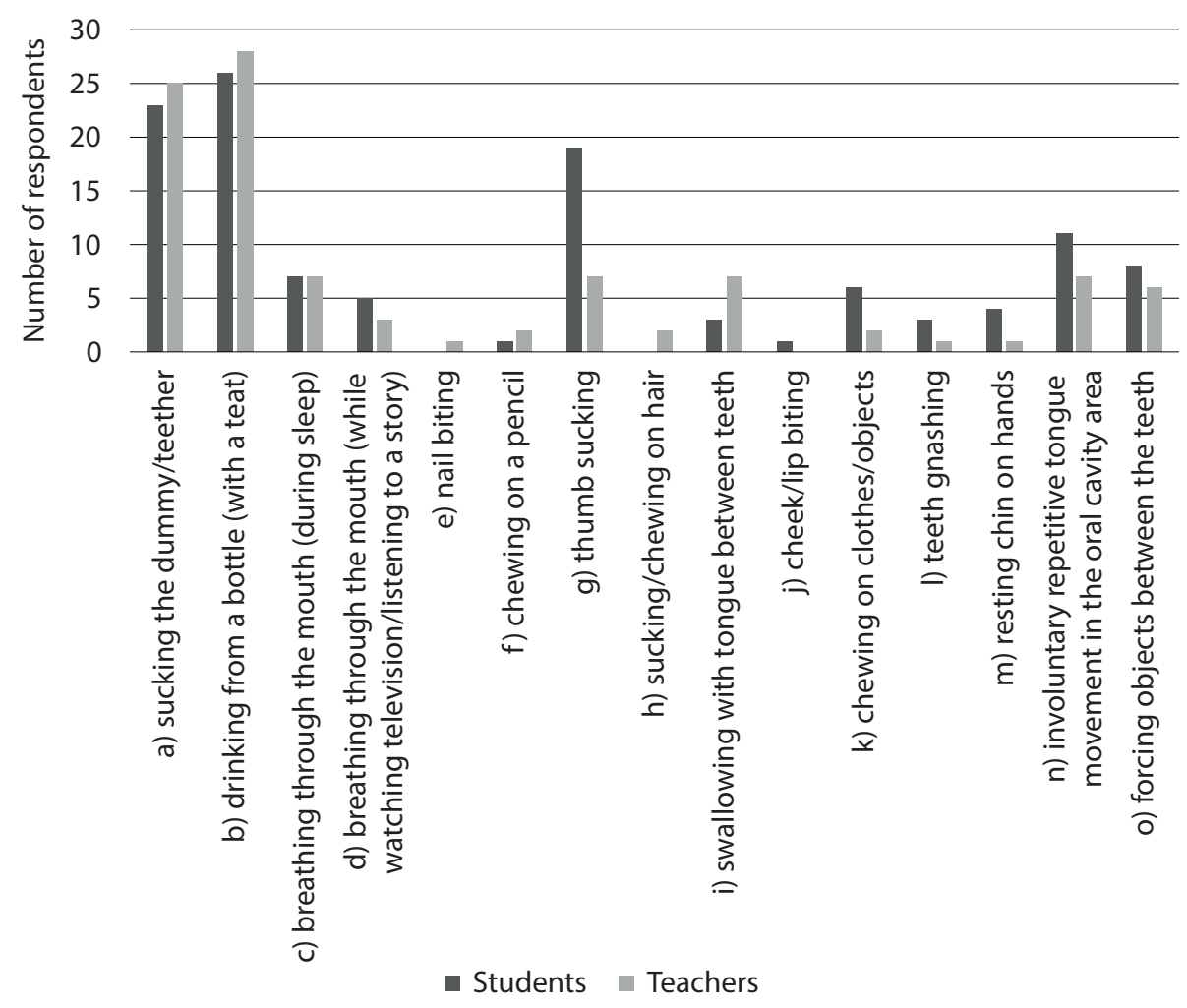

Chart 1. Activities considered to be permissible by students and teachers

Source: own study.

The respondents who deemed the given activity harmless were additionally asked to indicate the age of the child up to which it is not a deviation from the norm. Thus, for instance, sucking the dummy/teether is considered normal up to the age of 1 by 22 students and 23 teachers and up to the age of 3 by 1 student and 1 teacher. The activity of drinking from a bottle (with a teat) is deemed normal up to the age of 1 by 17 students and 25 teachers, while 9 students and 3 teachers think this is normal up to the age of 3 . Breathing through the mouth (during sleep) or while watching television or listening to a story as well as nail biting and chewing on a pencil 
are accepted by 1 student and 1 teacher up to the age of 7 . According to 17 students and 4 teachers, thumb sucking by a child is a normal activity (up to the age of 1 ). It is worth recalling that putting fingers into the mouth and other types of orofacial activities in infancy represent a natural stage of speech development, so the respondents answered the question correctly. In the opinion of 2 students and 1 teacher thumb sucking is a normal activity in children up to the age of 3 , one of the teachers considered this activity to be within the norm even in a 7-year-old child.

The analyzed teachers and students were also asked which of the listed activities should be regarded as impermissible or abnormal. The answers of the respondents from both groups are presented in Chart 2.

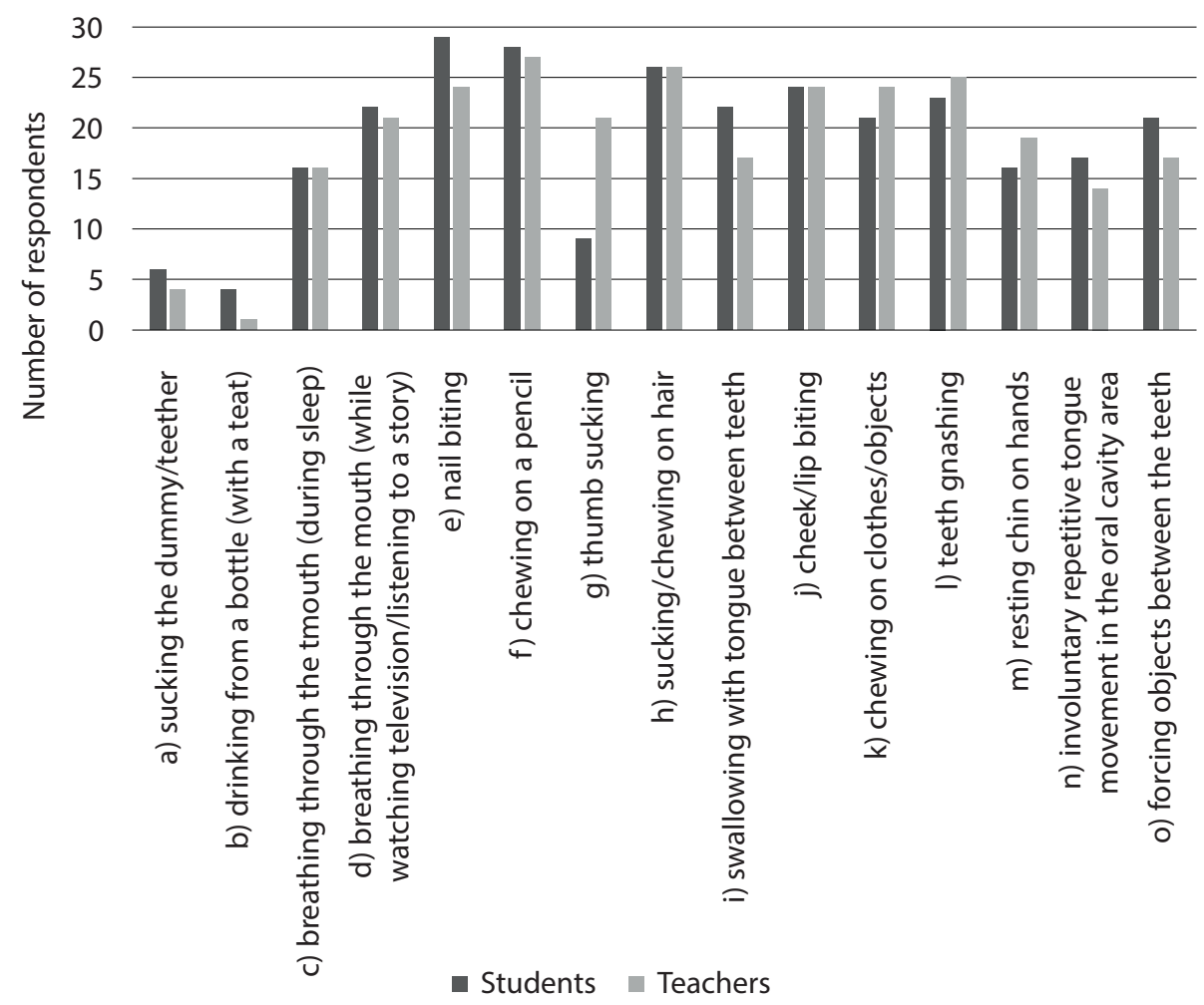

Chart 2. Activities considered to be impermissible by students and teachers

Source: own study.

The answers of the students included: nail biting as selected by $97 \%$ of respondents; chewing on a pencil (93\%); sucking/chewing on hair (87\%); cheek/lip biting (80\%); teeth gnashing (76\%); sucking/chewing on hair and breathing through the mouth while watching television or listening to a story $(73 \%)$; chewing on clothes or objects and forcing objects between the teeth (70\%). Involuntary repetitive tongue movement in the oral cavity area was indicated by $57 \%$ of students; breathing through the 
mouth (during sleep) and resting chin on hands (53\%); thumb sucking (30\%); sucking the dummy/teether $(20 \%)$ as well as drinking from a bottle with a teat marked by $13 \%$ of students. In the case of teachers, chewing on a pencil was chosen by $90 \%$ of respondents, sucking/chewing on hair (87\%), teeth gnashing (83\%), nail biting, cheek/lip biting as well as chewing on clothes or objects (80\%). Breathing through the mouth (e.g. while watching television or listening to a story) as well as thumb sucking were indicated as abnormal activities by $70 \%$ of teachers; resting chin on hands $(63 \%)$; swallowing with the tongue between the teeth and forcing objects between the teeth (57\%); breathing through the mouth during sleep (53\%); involuntary repetitive tongue movement in the oral cavity area (47\%); sucking the dummy/teether $(13 \%)$ and drinking with a teat $(3 \%)$.

The purpose of one of the questions from the survey was to get to know the opinions of students and teachers on the impact of activities classified as dysfunctions and parafunctions of the orofacial complex on the occurrence of speech impediments and abnormal course of speech development. The answers which they could choose from included: they definitely do not promote the development of speech impediments and they do not adversely affect speech development, they do not generally affect the occurrence of speech impediments, it is difficult to say whether they affect abnormal development of articulation, they generally or definitely promote the development of speech impediments and adversely affect speech development.

\section{Respondents' knowledge of the relationship between the parafunctions and dysfunctions of the oral-facial complex and articulatory disorders}

Table 1 illustrates the precise number size distribution and the percentage distribution of the answers of the surveyed students and teachers who regarded the activities as definitely not causing speech impediments.

Table 1. Activities which definitely do not cause speech impediments according to students and teachers

\begin{tabular}{|l|c|c|c|c|c|c|}
\hline \multicolumn{1}{|c|}{ Activity } & \multicolumn{2}{l}{$\begin{array}{l}\text { Students } \\
(n=30)\end{array}$} & \multicolumn{2}{|c|}{$\begin{array}{c}\text { Teachers } \\
(n=30)\end{array}$} & \multicolumn{2}{|c|}{$\begin{array}{c}\text { In total } \\
(n=60)\end{array}$} \\
\cline { 2 - 10 } & {$[n]$} & {$[\%]$} & {$[n]$} & {$[\%]$} & {$[n]$} & {$[\%]$} \\
\hline a) sucking the dummy/teether & 0 & 0 & 0 & 0 & 0 & 0 \\
\hline b) drinking from a bottle (with a teat) & 0 & 0 & 0 & 0 & 0 & 0 \\
\hline c) breathing through the mouth (during sleep) & 3 & 10 & 1 & 3 & 4 & 7 \\
\hline $\begin{array}{l}\text { d) breathing through the mouth (while watching television/ } \\
\text { listening to a story) }\end{array}$ & 3 & 10 & 1 & 3 & 4 & 7 \\
\hline e) nail biting & 2 & & & & & \\
\hline f) chewing on a pencil & 2 & 7 & 1 & 3 & 3 & 5 \\
\hline g) thumb sucking & 0 & 0 & 0 & 0 & 0 & 0 \\
\hline h) sucking/chewing on hair & 1 & 3 & 1 & 3 & 2 & 3 \\
\hline
\end{tabular}




\begin{tabular}{|l|c|c|c|c|c|c|}
\hline \multicolumn{1}{|c|}{ Activity } & \multicolumn{2}{c|}{$\begin{array}{l}\text { Students } \\
(n=30)\end{array}$} & \multicolumn{2}{|c|}{$\begin{array}{c}\text { Teachers } \\
(n=30)\end{array}$} & \multicolumn{2}{c|}{$\begin{array}{c}\text { In total } \\
(n=60)\end{array}$} \\
\cline { 2 - 9 } & {$[n]$} & {$[\%]$} & {$[n]$} & {$[\%]$} & {$[n]$} & {$[\%]$} \\
\hline i) swallowing with tongue between teeth & 0 & 0 & 0 & 0 & 0 & 0 \\
\hline j) cheek/lip biting & 3 & 10 & 0 & 0 & 3 & 5 \\
\hline k) chewing on clothes/objects & 2 & 7 & 0 & 0 & 2 & 3 \\
\hline l) teeth gnashing & 0 & 0 & 0 & 0 & 0 & 0 \\
\hline m) resting chin on hands & 3 & 10 & 0 & 0 & 3 & 5 \\
\hline n) involuntary repetitive tongue movement in the oral cavity area & 5 & 17 & 0 & 0 & 5 & 8 \\
\hline o) forcing objects between the teeth & 1 & 3 & 0 & 0 & 1 & 2 \\
\hline
\end{tabular}

Source: own study.

According to the students, activities which definitely do not cause articulation disorders and do not adversely affect speech development include involuntary excessive tongue movement in the oral cavity area as selected by 5 respondents as well as breathing through the mouth during sleep and while watching television, cheek/ lip biting as well as resting chin on hands (such answers were given by 3 respondents). In the opinion of one teacher, activities which definitely do not cause articulation disorders and do not adversely affect speech development include: breathing through the mouth (during sleep) and while watching television/listening to a story; nail biting; chewing on a pencil; or sucking/chewing on hair.

Table 2 presents the percentage of activities marked by the surveyed students and teachers which generally do not affect the occurrence of speech impediments and speech development disorders.

Table 2. Activities which "generally" do not affect the occurrence of speech impediments according to students and teachers

\begin{tabular}{|l|r|r|r|r|r|r|}
\hline \multirow{2}{*}{ Activity } & \multicolumn{2}{c|}{$\begin{array}{c}\text { Students } \\
(n=30)\end{array}$} & \multicolumn{2}{|c|}{$\begin{array}{c}\text { Teachers } \\
(n=30)\end{array}$} & \multicolumn{2}{|c|}{$\begin{array}{c}\text { In total } \\
(n=60)\end{array}$} \\
\cline { 2 - 10 } & {$[n]$} & {$[\%]$} & {$[n]$} & {$[\%]$} & {$[n]$} & {$[\%]$} \\
\hline a) sucking the dummy/teether & 8 & 27 & 1 & 3 & 9 & 15 \\
\hline b) drinking from a bottle (with a teat) & 8 & 27 & 2 & 7 & 10 & 17 \\
\hline c) breathing through the mouth (during sleep) & 10 & 33 & 0 & 0 & 10 & 17 \\
\hline $\begin{array}{l}\text { d) breathing through the mouth (while watching television/ } \\
\text { listening to a story) }\end{array}$ & 9 & 30 & 0 & 0 & 9 & 15 \\
\hline e) nail biting & 10 & 33 & 4 & 13 & 14 & 23 \\
\hline f) chewing on a pencil & 6 & 20 & 3 & 10 & 9 & 15 \\
\hline g) thumb sucking & 3 & 10 & 0 & 0 & 3 & 5 \\
\hline h) sucking/chewing on hair & 6 & 20 & 2 & 7 & 8 & 13 \\
\hline i) swallowing with tongue between teeth & 5 & 17 & 0 & 0 & 5 & 8 \\
\hline j) cheek/lip biting & 6 & 20 & 1 & 3 & 7 & 12 \\
\hline k) chewing on clothes/objects & 9 & 30 & 1 & 3 & 10 & 17 \\
\hline
\end{tabular}




\begin{tabular}{|l|c|c|c|c|c|c|c|}
\hline \multirow{2}{*}{ Activity } & \multicolumn{2}{|c|}{$\begin{array}{c}\text { Students } \\
(n=30)\end{array}$} & \multicolumn{2}{c|}{$\begin{array}{c}\text { Teachers } \\
(n=30)\end{array}$} & \multicolumn{2}{|c|}{$\begin{array}{c}\text { In total } \\
(n=60)\end{array}$} \\
\cline { 2 - 10 } & {$[n]$} & {$[\%]$} & {$[n]$} & {$[\%]$} & {$[n]$} & {$[\%]$} \\
\hline I) teeth gnashing & 4 & 13 & 1 & 3 & 5 & 8 \\
\hline m) resting chin on hands & 7 & 23 & 3 & 10 & 10 & 17 \\
\hline $\begin{array}{l}\text { n) involuntary repetitive tongue movement in the oral cavity } \\
\text { area }\end{array}$ & 9 & 30 & 0 & 0 & 9 & 15 \\
\hline o) forcing objects between the teeth & 7 & 23 & 1 & 3 & 8 & 13 \\
\hline
\end{tabular}

Source: own study.

The activities which "generally" do not cause speech impediments include breathing through the mouth (during sleep) and nail biting for 33\% of students while chewing on clothes or objects was marked by $30 \%$ of students. According to $13 \%$ of teachers nail biting belongs to the activities which "generally" do not cause speech disorders whereas $10 \%$ of teachers indicated chewing on a pencil and resting chin on hands.

Table 3 illustrates answers of the respondents who admitted that it is difficult to decide whether dysfunctions and parafunctions of the orofacial complex have an impact on abnormal development of articulation.

Table 3. Activities with regard to which it is difficult to say whether they have an impact on the abnormal development of articulation or not in the opinion of students and teachers

\begin{tabular}{|c|c|c|c|c|c|c|}
\hline \multirow[t]{2}{*}{ Activity } & \multicolumn{2}{|c|}{$\begin{array}{l}\text { Students } \\
(n=30)\end{array}$} & \multicolumn{2}{|c|}{$\begin{array}{l}\text { Teachers } \\
(n=30)\end{array}$} & \multicolumn{2}{|c|}{$\begin{array}{l}\text { In total } \\
(n=60)\end{array}$} \\
\hline & {$[n]$} & {$[\%]$} & {$[n]$} & [\%] & {$[n]$} & {$[\%]$} \\
\hline a) sucking the dummy/teether & 6 & 20 & 2 & 7 & 8 & 13 \\
\hline b) drinking from a bottle (with a teat) & 7 & 23 & 1 & 3 & 8 & 13 \\
\hline c) breathing through the mouth (during sleep) & 13 & 43 & 8 & 27 & 21 & 35 \\
\hline $\begin{array}{l}\text { d) breathing through the mouth (while watching television/ } \\
\text { listening to a story) }\end{array}$ & 11 & 37 & 9 & 30 & 20 & 33 \\
\hline e) nail biting & 6 & 20 & 7 & 23 & 13 & 22 \\
\hline f) chewing on a pencil & 4 & 13 & 7 & 23 & 11 & 18 \\
\hline g) thumb sucking & 6 & 20 & 1 & 3 & 7 & 12 \\
\hline h) sucking/chewing on hair & 14 & 47 & 6 & 20 & 20 & 33 \\
\hline i) swallowing with tongue between teeth & 9 & 30 & 6 & 20 & 15 & 25 \\
\hline j) cheek/lip biting & 6 & 20 & 11 & 37 & 17 & 28 \\
\hline k) chewing on clothes/objects & 4 & 13 & 11 & 37 & 15 & 25 \\
\hline I) teeth gnashing & 8 & 27 & 11 & 37 & 19 & 32 \\
\hline m) resting chin on hands & 7 & 23 & 9 & 30 & 16 & 27 \\
\hline $\begin{array}{l}\text { n) involuntary repetitive tongue movement in the oral cavity } \\
\text { area }\end{array}$ & 6 & 20 & 11 & 37 & 17 & 28 \\
\hline o) forcing objects between the teeth & 3 & 10 & 8 & 27 & 11 & 18 \\
\hline
\end{tabular}

Source: own study. 
In the case of the answer "it is difficult to say", $47 \%$ of students pointed to sucking/chewing on hair. The remaining answers also included: breathing through the mouth during sleep as selected by $43 \%$ students and breathing through the mouth while watching television/listening to a story, which was indicated by $37 \%$ of the respondents. In the case of teachers $37 \%$ of them marked cheek/lip biting, chewing on clothes or objects, teeth gnashing and involuntary excessive tongue movement in the oral cavity area.

Both number and percentage values are presented in Table 4 and they represent a set of answers of students and teachers who described the given activities as "generally" affecting the development of speech impediments.

Table 4. Activities which "generally" have an impact on the occurrence of speech impediments according to students and teachers

\begin{tabular}{|l|r|r|r|r|c|c|}
\hline \multirow{2}{*}{ Activity } & \multicolumn{2}{|c|}{$\begin{array}{c}\text { Students } \\
(n=30)\end{array}$} & \multicolumn{2}{|c|}{$\begin{array}{c}\text { Teachers } \\
(n=30)\end{array}$} & \multicolumn{2}{|c|}{$\begin{array}{c}\text { In total } \\
(n=60)\end{array}$} \\
\cline { 2 - 10 } & {$[n]$} & {$[\%]$} & {$[n]$} & {$[\%]$} & {$[n]$} & {$[\%]$} \\
\hline a) sucking the dummy/teether & 11 & 37 & 5 & 17 & 16 & 27 \\
\hline b) drinking from a bottle (with a teat) & 13 & 43 & 8 & 27 & 21 & 35 \\
\hline c) breathing through the mouth (during sleep) & 2 & 7 & 10 & 33 & 12 & 20 \\
\hline $\begin{array}{l}\text { d) breathing through the mouth (while watching television/ } \\
\text { listening to a story) }\end{array}$ & 4 & 13 & 12 & 40 & 16 & 27 \\
\hline e) nail biting & 8 & 27 & 8 & 27 & 16 & 27 \\
\hline f) chewing on a pencil & 14 & 47 & 10 & 33 & 24 & 40 \\
\hline g) thumb sucking & 15 & 50 & 10 & 33 & 25 & 42 \\
\hline h) sucking/chewing on hair & 4 & 13 & 12 & 40 & 16 & 27 \\
\hline i) swallowing with tongue between teeth & 15 & 50 & 14 & 47 & 29 & 48 \\
\hline j) cheek/lip biting & 13 & 43 & 11 & 37 & 24 & 40 \\
\hline k) chewing on clothes/objects & 12 & 40 & 9 & 30 & 21 & 35 \\
\hline l) teeth gnashing & 10 & 33 & 10 & 33 & 20 & 33 \\
\hline m) resting chin on hands & 8 & 27 & 9 & 30 & 17 & 28 \\
\hline $\begin{array}{l}\text { n) involuntary repetitive tongue movement in the oral cavity } \\
\text { area }\end{array}$ & 8 & 27 & 10 & 33 & 18 & 30 \\
\hline o) forcing objects between the teeth & 9 & 30 & 13 & 43 & 22 & 37 \\
\hline
\end{tabular}

Source: own study.

Swallowing with tongue between teeth is an activity which "generally" causes disorders in normal speech development according to $50 \%$ of students. As it was mentioned earlier, thumb sucking is deemed harmless by $63 \%$ students. At the same time $50 \%$ of the analysed students gave the answer that thumb sucking may "generally" cause speech impediments. Activities which "generally" cause disorders in normal speech development include swallowing with tongue between teeth according to $46 \%$ of teachers and forcing objects between the teeth in the opinion of $43 \%$ of the respondents. 
Table 5 illustrates the precise number size distribution and the percentage distribution of the answers of the surveyed students and teachers who regarded the activities as definitely causing speech impediments.

Table 5. Activities which definitely have an impact on the occurrence of speech impediments according to students and teachers

\begin{tabular}{|c|c|c|c|c|c|c|}
\hline \multirow[t]{2}{*}{ Activity } & \multicolumn{2}{|c|}{$\begin{array}{l}\text { Students } \\
(n=30)\end{array}$} & \multicolumn{2}{|c|}{$\begin{array}{l}\text { Teachers } \\
(n=30)\end{array}$} & \multicolumn{2}{|c|}{$\begin{array}{l}\text { In total } \\
(n=60)\end{array}$} \\
\hline & {$[n]$} & [\%] & {$[n]$} & [\%] & {$[n]$} & [\%] \\
\hline a) sucking the dummy/teether & 5 & 17 & 22 & 73 & 27 & 45 \\
\hline b) drinking from a bottle (with a teat) & 2 & 7 & 19 & 63 & 21 & 35 \\
\hline c) breathing through the mouth (during sleep) & 2 & 7 & 11 & 37 & 13 & 22 \\
\hline $\begin{array}{l}\text { d) breathing through the mouth (while watching television/ } \\
\text { listening to a story) }\end{array}$ & 3 & 10 & 8 & 27 & 11 & 18 \\
\hline e) nail biting & 4 & 13 & 10 & 33 & 14 & 23 \\
\hline f) biting pencils & 4 & 13 & 9 & 30 & 13 & 22 \\
\hline g) thumb sucking & 6 & 20 & 19 & 63 & 25 & 42 \\
\hline h) sucking/biting hair & 5 & 17 & 9 & 30 & 14 & 23 \\
\hline i) swallowing with tongue between teeth & 1 & 3 & 10 & 33 & 11 & 18 \\
\hline j) cheek/lip biting & 2 & 7 & 7 & 23 & 9 & 15 \\
\hline k) chewing on clothes/objects & 3 & 10 & 9 & 30 & 12 & 20 \\
\hline I) teeth gnashing & 8 & 27 & 8 & 27 & 16 & 27 \\
\hline m) resting chin on hands & 5 & 17 & 9 & 30 & 14 & 23 \\
\hline $\begin{array}{l}\text { n) involuntary repetitive tongue movement in the oral cavity } \\
\text { area }\end{array}$ & 2 & 7 & 9 & 30 & 11 & 18 \\
\hline o) forcing objects between the teeth & 10 & 33 & 8 & 27 & 18 & 30 \\
\hline
\end{tabular}

Source: own study.

Forcing objects between the teeth was considered to be the activity which promotes the development of articulation disorders the most by 10 students. Other answers included teeth gnashing chosen by 8 respondents and thumb sucking marked by $20 \%$ of respondents. Feeding with a bottle with a teat may definitely have an adverse effect on speech development in the opinion of $63 \%$ teachers. Interestingly, as indicated by the vast majority of teachers ( 22 of them), sucking the dummy/teether promotes the development of speech impediments the most. In the case of students, such an answer was given by merely 5 respondents.

The aim of the subsequent question directed to both respondent groups was to generally assess the impact of the dysfunctions and parafunctions of the orofacial complex on the development of speech impediments. The vast majority of students (87\%) and teachers (70\%) agreed that the activities listed in the survey are one of the causes of speech impediments. $13 \%$ of students and $30 \%$ of teachers regarded them as the main reason for the development of articulation disorders, whilst none of respondents selected the answer that the listed activities do not cause speech impediments. 


\section{Knowledge of the respondents on the prevention of dysfunctions and parafunctions of the oral-facial syndrome}

The question "Do you know how to prevent the occurrence of activities listed in Table 5 ?" was answered in the positive by merely $17 \%$ of students $(n=5)$ and $63 \%$ of teachers $(n=19)$. Such an appreciable difference between the respondents' answers should be explained by greater professional and life experience (the fact of being a parent) ${ }^{2}$ of teachers. The respondents were additionally asked to give examples of preventing the disorders of the orofacial complex. According to students, it is advisable to 3: "conduct speech therapy classes, breathing exercises" or "draw children's attention to abnormal activities, show them how to cope with stress and negative emotions". Out of 19 teachers who confirmed that they knew how to prevent the aforementioned abnormalities, only 14 people gave concrete examples of such activities. Teachers, for instance, suggested that "it is possible to wean the child off sucking the dummy giving it during the bedtime routine its favourite teddy bear, blanket or terry nappy, which the child may cuddle to", "it is necessary to educate parents and make them aware of the reasons and their origins of speech impediments and also malocclusion". In addition, they proposed "controlling bad habits, e.g. nail biting", "not forcing the dummy if the child is not interested in sucking it", "weaning the child off sucking the thumb and putting different objects into the mouth as soon as possible", "diagnosing the cause of sleeping with the mouth open".

\section{Opinions of the respondents on the justifiability of teaching of pre-school education and early childhood education teachers in the field of basic knowledge about the anomalies of the oral-facial complex}

All teachers and $99 \%$ of students confirmed that teachers of kindergartens and the first three classes of primary school need the knowledge on the activities of the orofacial complex 4 . Here are the justifications of students: "it is important that the teacher is aware of them so as to shape correct articulation and pay attention to his or her own habits which are modelled by children through copying", "teachers should have knowledge on this topic so as to prevent in this period subsequent articulation problems", "thanks to this the child may be spared meetings with the speech therapist or wearing uncomfortable braces" and "so as to react quickly if some activities of the orofacial complex occur".

2 The authors of the article assumed that few students have experience of parenthood.

3 The paper quotes examples of concrete activities preventing the development and perpetuation of abnormalities of the oral-facial complex which were given by the surveyed students and teachers.

4 In this question the term "the orofacial complex" was consciously used in order to verify the respondents' knowledge in this respect.

5 Also in this case the authors preserved the original style of the answers given by respondents.

6 Probably the person who gave this answer meant the reaction in the case of the occurrence of some ABNORMALITIES with regard to the orofacial complex. 
Educators, in turn, gave the following arguments: "teachers may contribute to eliminating factors causing speech impediments in children at least to a slight degree", "a teacher having the knowledge on this complex may suggest to parents that they should visit a specialist if the child displays some alarming activities related to the orofacial complex", "if the child has a malocclusion, the teacher should know that this abnormality may distort the correct realization of some sounds". One of the analyzed teachers gave the following answer: "the teacher will be able to support and stimulate the correct development of a child" with the post scriptum "I do not know what the orofacial complex is" 7 . The answers also included the following opinion: "my work experience allows me to confirm without doubt that speech impediments are an extremely frequent problem in pre-school children", which is convergent with the professional practice of the authors of the article and scientific research findings yet it fails to answer the question asked.

The respondents were asked to assess the state of their knowledge on the orofacial complex. The answers of the respondents are presented in Chart 3.

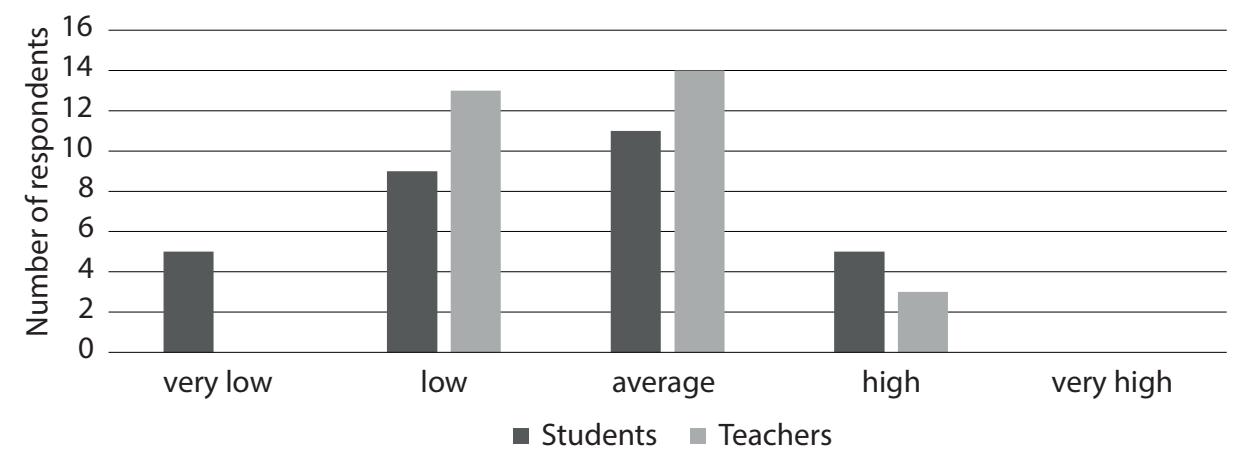

Chart 3. Assessment of the state of the knowledge on the orofacial complex according to students and teachers

Source: own study.

11 students and 14 teachers assessed the state of their knowledge on the orofacial complex as average. 5 students considered their competences in the discussed field as "very low" while none of the teachers marked this option. 9 students and 13 teachers described the state of their knowledge as "low". 5 students and 3 teachers assessed their competences in the discussed area as "high", yet none of the respondents considered them to be "very high". The answers of the students show that in the course of their studies (the respondents were third-year BA students in the summer term) none of them took part in any classes on language communication and its disorders. They participated, instead, in classes "Voice emission with elements of vocal

7 This example shows that the teacher is aware of knowledge deficiencies but tries to give some answer, perhaps on the assumption that the educator should "know everything". 
arts" and "Live word in working with a small child", which in their opinion did not account for the content related to speech development and disorders, including abnormalities within the orofacial complex. Only 7 teachers $(23 \%)$ indicated that they got acquainted with the basics of speech therapy during their studies.

In the response to the question "Do you feel that your knowledge on the orofacial complex is insufficient?" $99 \%$ students and $100 \%$ of teachers replied in the positive. All respondents also stated that the knowledge on abnormalities of the orofacial complex should be disseminated among parents of pre-school children.

\section{Conclusions}

The research results show that the knowledge of students and teachers of pre-school and early school education on the dysfunctions and parafunctions of the orofacial complex is insufficient. Teachers gave slightly more corrected answers concerning the disorders of the orofacial complex than students. This may be due to the greater professional and parental experience of teachers. Among the answers of the respondents confirming their insufficient knowledge on abnormalities of the orofacial complex, there were some contradictory opinions, e.g. $63 \%$ of analyzed students considered, on the one hand, thumb sucking to be harmless but, on the other, as many as half of them marked that it may cause speech impediments.

Despite the fact that $17 \%$ students and $63 \%$ of teachers declare that they have the competencies for the prevention of the dysfunctions and parafunctions of the orofacial complex, most of them are not able to give a concrete example of such an activity, giving only some generalities.

In the opinion of the respondents, the teacher is the first person who may identify early abnormalities of the stomatognathic system, implement prophylactic measures as well as talk to the parent on the dysfunctions and parafunctions observed in a child. Therefore is seems justifiable to say that the basics of knowledge on speech therapy should be propagated among students and teachers of early school and pre-school education. The content of the curriculum for teachers who are preparing to work with children at preschool and early school age should include the basics of speech therapy, including the knowledge on the orofacial complex. Regrettably, the opinions of students taking part in the research imply that academic classes fail to provide students with even basic information on speech disorders and their conditionings which include the abnormalities of the orofacial complex. This is confirmed by research conducted by Ewa Gacka, who stressed that no classes on speech therapy could be found in the curriculum of the specialization of preschool and early school education as well as childhood education at Lodz University in the 2012/2013 academic year [Gacka, 2013a, p. 53]. 
The conducted research justifies the necessity of extending the curriculum of future teachers of preschool and early school education by adding contents connected with the conditions of normal speech development and detection of the first symptoms of abnormalities in language communication development. Only a well-educated teacher in cooperation with the speech therapist may not only contribute to accelerating the diagnosis but also assist in implementing the therapeutic process and elimination of the child's bad habits.

\section{References}

Błachnio K., 2012, Vademecum logopedyczne: dla studentów pedagogiki, Poznań: Wydawnictwo Uniwersytetu Adama Mickiewicza.

Gacka E., 2013a, Pedagodzy w systemie opieki logopedycznej. Refleksje nad treściami logopedycznymi w kształceniu studentów kierunku pedagogika, [in:] D. Muller, A. Sobczak (eds.), Rozwój i jego wspieranie w perspektywie rehabilitacji i resocjalizacji, Łódź: Wydawnictwo Uniwersytetu Łódzkiego, pp. 47-58.

Gacka E., 2013b, Współpraca logopedy i nauczyciela w opiece nad dzieckiem z opóźnionym rozwojem mowy, [in:] K. Węsierska, N. Moćko (eds.), Profilaktyka logopedyczna w praktyce edukacyjnej, vol. II, Katowice: Wydawnictwo Uniwersytetu Śląskiego, pp. 53-65.

Grosfeldowa O., 1981, Wady twarzowo-szczękowo-zgryzowe, [in:] A. Masztelarz (ed.), Zarys ortopedii szczękowej - ortodoncji. Podręcznik dla studentów stomatologii, Warszawa: Wydawnictwo Lekarskie PZWL.

Kleinrok M., 1992, Zaburzenia czynnościowe układu ruchowego narządu żucia, Warszawa: Sanmedia.

Łabiszewska-Jaruzelska F., 1983, Etiologia zaburzeń w obrębie narządu żucia, [in:] F. ŁabiszewskaJaruzelska (ed.), Ortopedia szczękowa - zasady i praktyka, Warszawa: Wydawnictwo Lekarskie PZWL, pp. 140-176.

Łobocki M., 2006, Metody i techniki badań pedagogicznych, Kraków: Oficyna Wydawnicza Impuls.

Malicka I., 2017, Przegląd badań dotyczacych dysfunkcji mowy, "Annales Universitatis Paedagogicae Cracoviensis. Studia Logopaedica VI”, vol. 225, pp. 101-112.

Masztelarz A., 1981, Morfologia zespołu ustno-twarzowego, [in:] A. Masztelarz (ed.), Zarys ortopedii szczękowej - ortodoncji. Podręcznik dla studentów stomatologii, Warszawa: Wydawnictwo Lekarskie PZWL, pp. 18-30.

Pilch T., Bauman T., 2001, Zasady badań pedagogicznych. Strategie ilościowe i jakościowe, Warszawa: Wydawnictwo Akademickie "Żak".

Pluta-Wojciechowska D., 2011, Mowa dzieci z rozszczepem wargi i podniebienia, Kraków: Wydawnictwo Uniwersytetu Pedagogicznego.

Pluta-Wojciechowska D., 2017, Dyslalia obwodowa. Diagnoza i terapia logopedyczna wybranych form zaburzeń, Bytom: Wydawnictwo Ergo Sum.

Rokitiańska M., 2004, Podstawy ortodoncji dla logopedów, Bydgoszcz: Wydawnictwo Akademii Bydgoskiej.

Zadurska M., Siemińska-Piekarczyk B., Wierusz W., Mysiorska M., Kosińska K., 2007, Ocena wspótzależności występowania wady zgryzu, wady artykulacji i dysfunkcji narządu żucia u dzieci z przedszkoli warszawskich, "Stomatologia Współczesna”, supplement 2, pp. 17-24. 


\section{Abstract}

Cooperation between educators and speech therapists represents an important element in the care of a child with speech disorders, including speech impediments. Teachers should also have the minimum of knowledge on speech therapy which will allow them to notice abnormalities in speech development in children as well as identify activities which promote the development of language communication disorders. The paper presents the findings of the research whose main aim was to present the level of knowledge of teachers and students of pre-school and early school education on abnormalities of the orofacial complex and their impact on the development of articulation disorders. In addition, the aim of the research was to get acquainted with the opinions of respondents on the need to educate teachers in this respect.

\section{Streszczenie}

Współpraca pomiędzy pedagogami i logopedami stanowi istotny element w opiece nad dziećmi z zaburzeniami mowy, w tym z wadami wymowy. Nauczyciele powinni posiadać niezbędne minimum wiedzy logopedycznej, która pozwoli im zauważyć u wychowanków nieprawidłowości w rozwoju mowy, a także zidentyfikować czynności sprzyjające powstaniu zaburzeń w zakresie komunikacji językowej. Artykuł stanowi doniesienie z badań, których głównym celem było przedstawienie poziomu wiedzy nauczycieli oraz studentów edukacji wczesnoszkolnej i wychowania przedszkolnego na temat nieprawidłowości zespołu ustno-twarzowego i ich wpływu na powstanie zaburzeń artykulacyjnych. Celem badań było także poznanie opinii respondentów na temat potrzeby kształcenia pedagogów w tym zakresie. 